\title{
Väestönmuutoksen ja väestönrakenteen alueellisista piirteistä Pohjois-Suomessa
}

\author{
HEIKKI PESONEN \\ Oulun yliopiston maantieteen laitos
}

Seuraavassa on tarkoitus käsitellä väestön kasvun ja vähenemisen alueellisia piirteitä Pohjois-Suomessa, jolla tässä tutkimuksessa tarkoitetaan Pohjois-Pohjanmaan, Kainuun ja Lapin tilastoalueista muodostettua kokonaisuutta. Tämä alue käsittää $45 \%$ koko maan pinta-alasta, mutta sillä elää vain 11 \% Suomen asukkaista (SVT VI C: 103 II, taulu 1). Tällaisenaan tutkimusalue vastaa suurin piirtein Luonnon-Suomeksi tai Reuna-Suomeksi nimitettyä osaa maastamme, jolle on ominaista pieni väentiheys ja harva tieverkosto, teollisuuden suhteellisen vähäinen kehittyneisyys sekä se, että ilmasto vaikeuttaa maatalouden harjoittamista (Aario 1966, 212 ja 260-278 ja Hustich 1960, 131-132). Epäsuotuisasta ilmastosta ja pienestä peltoalasta myös johtuu, että alueen maatalousväestö ei saa riittävää toimeentuloa maanviljelyksestä, vaan sen täytyy hankkia lisäansioita (Varjo 1965, 17). Näitä tarjoutuu lähinnä metsätalouden piiristä.

Alueellisten erojen selvittely perustuu kuntaa pienempien kansakoulupiireistä ja äänestysalueista muodostettujen alueyksiköiden käyttöön (kts. Hautamäki 1967). Yhdistämällä aina mahdollisuuksien mukaan kansakoulupiiri ja äänestysalue saatiin kahdenlaista aineistoa alueyksiköiden väestöstä. Niin sanottujen lokakuun 20 päivän ilmoitusten perusteella saatiin tiedot oppivelvollisten lukumääristä kansakoulupiireittäin ja henkikirjoittajilta saatiin tiedot äänioikeutettujen lukumääristä äänestysalueittain. Oppivelvollisiin kuuluvat 7-15-vuotiaat ja äänioikeutettuihin 21 vuotta täyttäneet eräitä rangaistusseuraamuksia kärsiviä lukuun ottamatta. Nämä ryhmät käsittävät noin $75 \%$ väestöstä. Koska kansakoulupiireittäiset tiedot on vain maaseudulta, koskee osa tutkimuksen selvityksistä vain maalaiskuntien alueita.

Tutkimusalueen laajuudesta johtuu, ettei kaikkien alueyksiköiden kohdalla ole voitu selvitellä niiden väestönrakenteeseen tai väestönmuutokseen vaikuttavia syitä. Tässä esitettyjen tietojen tarkoituksena onkin lähinnä kuvata väestöllisten tekijäin alueellisia vaihteluita pohjoisella kehitysalueella. Tämä suoritetaan toisaalta kartogrammien avulla, toisaalta tutkimalla korrelaatiolaskennan avulla väestöllisten ilmiöiden riippuvuussuh 


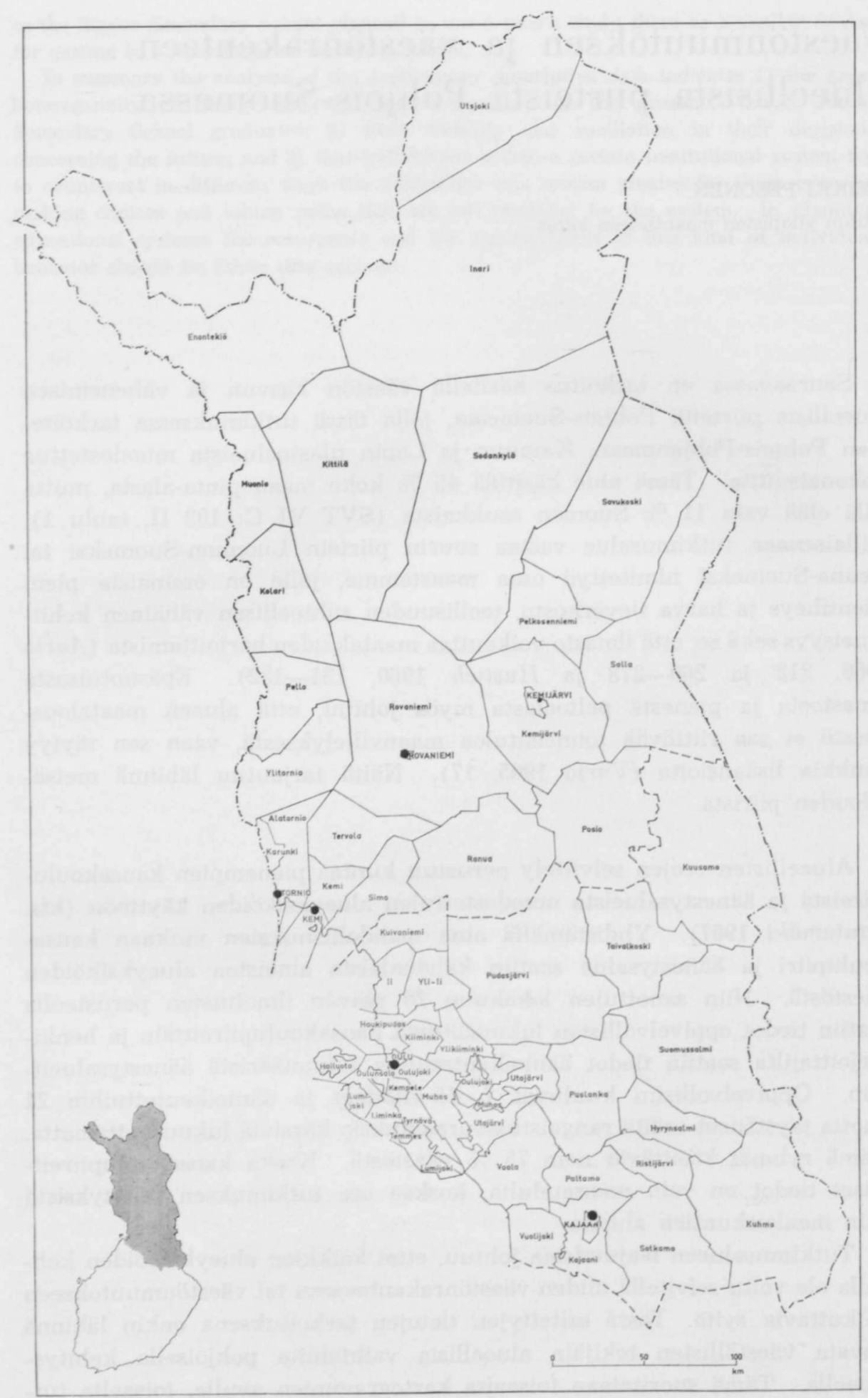


$\mathrm{Ku}$ vi o 1 . Tutkimusalueen kunnat.

Figure 1. Communes of the region under investigation.

$\mathrm{K}$ u vi o 2. Tutkimusalueen tärkeimmät vesistöt.

Figure 2. Major waterways of the region under investigation.

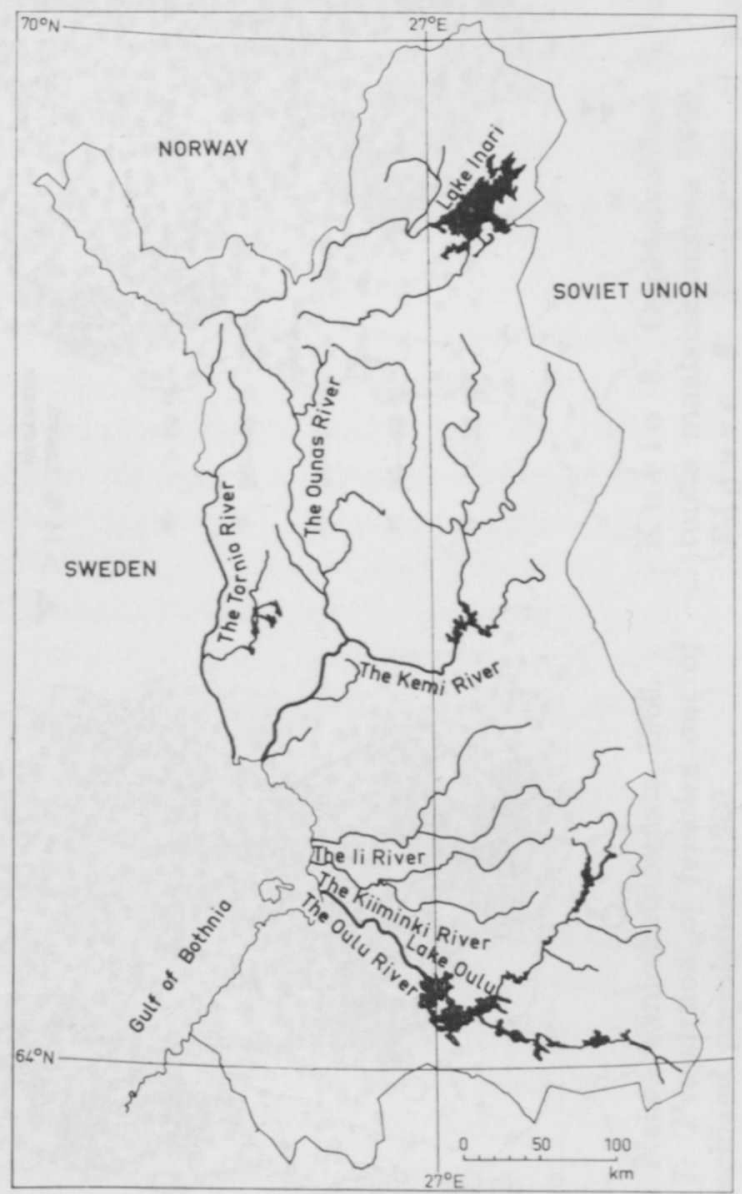

teita toisistaan ja lähinnä etäisyydeksi tai syrjäisyydeksi nimitetystä ekologisesta tekijästä. Tutkimusaineiston käsittelyssä, muun muassa kartogrammien piirtämisessä, on käytetty apuna automaattista tietojenkäsittelyä. Tämä on suoritettu nykyisen Nokia Osakeyhtiön ja Oulun yliopiston tietokonekeskuksissa.

\section{Tutkimusalueen pääosat}

Ekologisten olosuhteiden vaihtelua tutkimusalueella kuvaa kartogrammi sen väentiheydestä (kuvio 3 ). Alueyksikön väestömäärä on määritetty oppivelvollisten ja äänioikeutettujen yhteislukumäärän perusteella käyttämällä kunnittaista korjauskerrointa niiden ulkopuolelle jäävän väestön lukumäärän arviointiin. Näin saatu väkiluku on jaettu alueyksikön pintaalalla. Kartogrammi on sitten piirretty sijoittamalla alueyksikön väestölliseen painopisteeseen sen väentiheyttä vastaava merkki. Koska koulupiirien ja äänestysalueiden täytyy harvaan asutuilla seuduilla olla laajoja, 


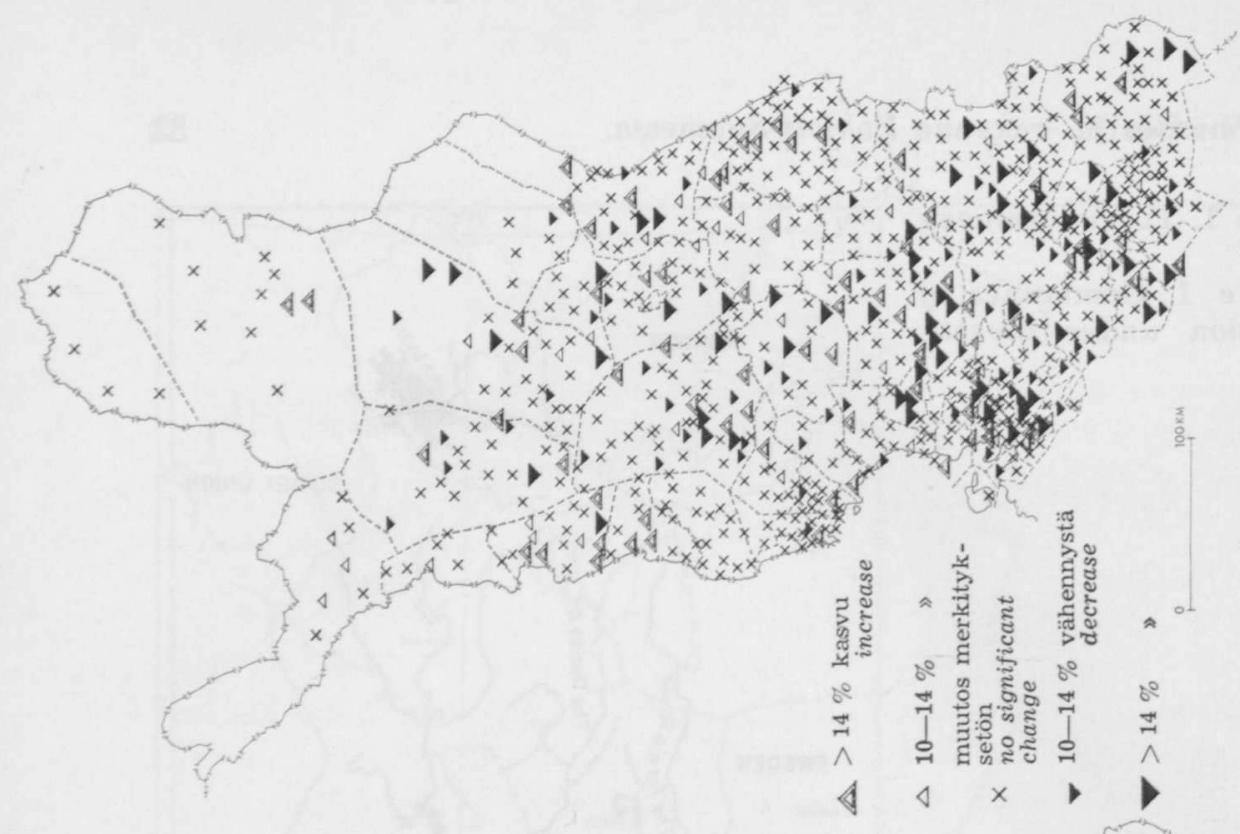

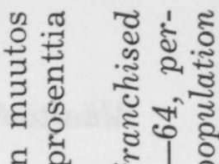
: है है। है 峁

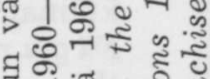

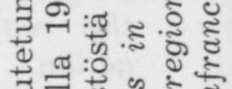
సै ส స్ य. Е

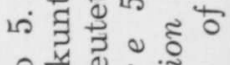

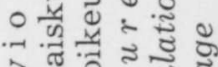
ᄀ สี

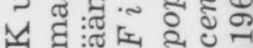
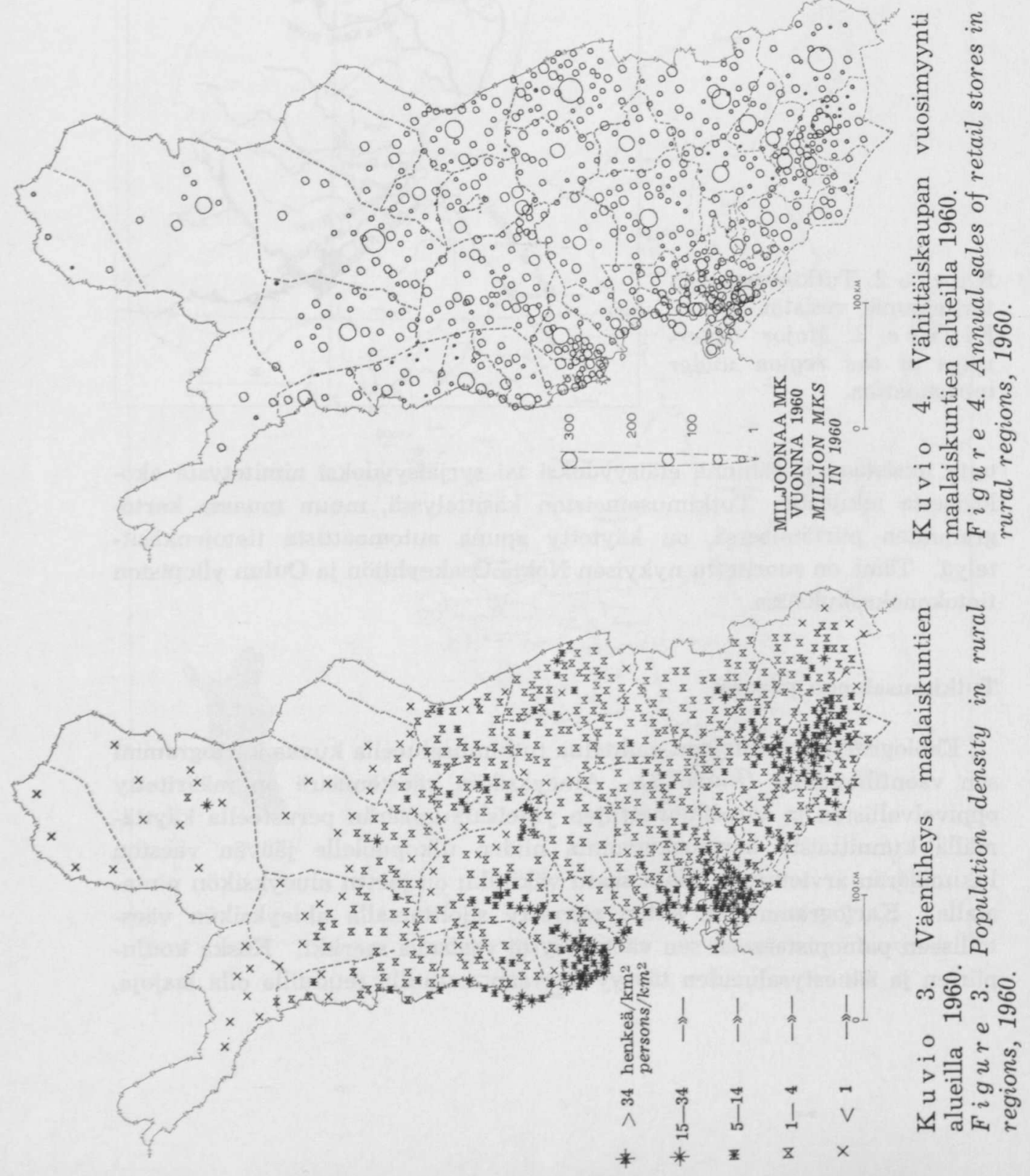

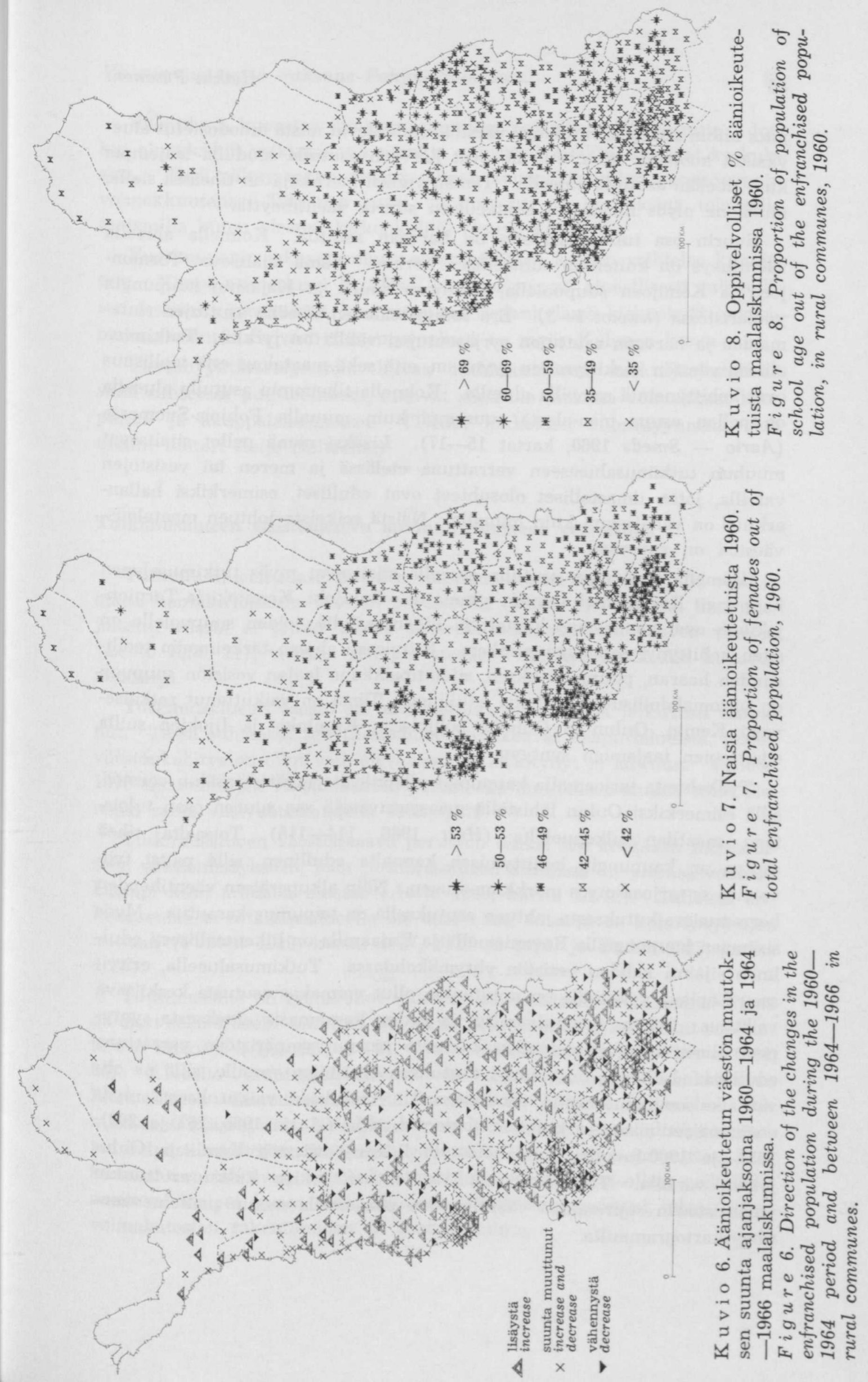
jotta niihin sisältyisi riittävästi väestöä, vaihtelevat niistä muodostetut alueyksiköt kooltaan siten, että ne ovat harvaan asutulla seudulla laajempia kuin tiheään asutulla alueella. Tämän vuoksi merkkejä on tiheässä siellä, missä ne myös ilmaisevat suhteellisen suurta väentiheyttä.

Suurin osa tutkimusaluetta on harvaan asuttua. Kolmella alueella väentiheys on kuitenkin suhteellisen korkea. Nämä sijaitsevat Tornionjoen ja Kemijoen suupuolella, Oulujoen suulla ja Kajaanin kaupungin ympäristössä (kuviot 1-3). Ero tutkimusalueen tiheään asuttujen rintamaiden ja harvaan asuttujen syrjäseutujen välillä on jyrkkä. Tutkimusalueen väestön keskittymisen syynä on, että sekä maatalous että teollisuus ovat kehittyneintä samoilla alueilla. Kolmella tiheimmin asutulla alueella on pellon osuus maa-alasta suurempi kuin muualla Pohjois-Suomessa (Aario - Smeds 1960, kartat 15-17). Lisäksi nämä pellot sijaitsevat muuhun tutkimusalueeseen verrattuna etelässä ja meren tai vesistöjen varsilla, joten ilmastolliset olosuhteet ovat edulliset, esimerkiksi hallanarkuus on vähäisempi kuin muualla. Näistä seikoista johtuen maatalousväestöä on runsaasti.

Kolmella tiheimmin asutulla alueella sijaitsevat myös tutkimusalueen kaupungit Rovaniemeä lukuun ottamatta. Oulujoki, Kemijoki ja Tornionjokihan ovat vanhastaan käytettyjä liikenneväyliä, joiden suupuolelle on siten kehittynyt satamakaupunkeja. Erityisesti alueen tärkeimmän teollisuuden haaran, puunjalostuksen, sijaintipaikkana laajan vesistön suupuoli on uittomahdollisuuksien takia edullinen. Tämä on vaikuttanut ratkaisevasti Kemin, Oulun ja Oulusta pohjoiseen Kiiminki- ja Iijokien suilla sijaitsevien taajamien syntyyn.

Työkohteita tarjoamalla kaupungit ylläpitävät ympäristönsäkin väestöä, sillä esimerkiksi Oulun lähistöllä maaseutuväestö saa suuren osan tuloistaan maatilan ulkopuolelta (Hult 1966, 114-115). Toisaalta tiheä asutus on kaupungin kehittymisen kannalta edullinen, sillä paitsi työvoimaa se tarjoaa myös markkina-alueen. Näin alkuperäisen väentiheyden kerrannaisvaikutuksesta johtuen asutuksella on taipumus kasautua. Myös sisämaan kaupungeilla Rovaniemellä ja Kajaanilla on liikenteellisesti edullinen sijainti kahden vesistön yhtymäkohdassa. Tutkimusalueella, erityisesti Lapissa, vesistöillä on muutenkin ollut voimakas asutusta keskittävä vaikutus. Jokivarsien tulvaniityt ja jokien kasaamasta aineksesta syntyneet alueet ovat maatalouden kannalta karuun ympäristöön verrattuna edullisia. Liikenne on vetänyt asutuksen vesistöjen varsille, sillä ne olivat aikaisemmin tärkeitä venereitteinä. Asutuksen vaikutuksesta myös ensimmäiset maantiet kulkivat jokien varsilla (Aario 1966, 267 ja 269). 1950- ja 1960-luvuilla voimalaitostyöt lisäsivät väestöä Kemi- ja Oulujokien varsilla. Tällaisista seikoista johtuen jokien kulku erottuukin ympäristöään suuremman väentiheyden perusteella monin paikoin väentiheyskartogrammilta. 
Väentiheys kuvastaa ihmisen toiminnan paikallista tehokkuutta. Jotkut alueyksiköt vaikuttavat kuitenkin ympäristöönsäkin, toimivat keskuksina. Tämä näkyy muun muassa niiden kauppaliikkeiden vuosimyynnin voimakkuutena. Tällainen suuri vuosimyynti on keskuksina toimivilla taajamilla kuten yleensä kirkonkylillä (kuvio 4).

Vuosimyynnin jakaantuminen alueyksiköiden kesken vaihtelee kunnittain. Niinpä esimerkiksi Kittilässä on vuosimyynti alueellisesti suhteellisen tasaisesti jakautunut, kun sensijaan Sodankylässä kirkonkylä on voimakas keskus. Selvästi samantyyppinen on myös Kuhmon kunta.

Vuosimyyntikartogrammi kuvaa tutkimusalueen keskusjärjestelmää siinä suhteessa puutteellisesti, etteivät siinä ole mukana voimakkaat kaupunki- ja kauppalakeskukset. (Tiedot liikkeiden vuosimyynnistä olen saanut tohtori Reijo Helteeltä.)

\section{Tutkimusalueen väestönkasvu muuhun Suomeen verrattuna}

Tutkimusalueen tilastoalueiden väestönmuutosta on seurattu 35 vuoden ajalta henkikirjoitetun väestön perusteella (kuvio 9). Vaikka henkikirjoitettu väestö ei täysin vastaa alueella todellisuudessa asuvaa väestöä (Lento 1956, 21), voidaan sen perusteella kuitenkin laatia sitä kuvaava aikasarja.

Tutkimusalueen väestö on tarkasteltuna ajanjaksona jatkuvasti kasvanut. Tässä suhteessa sen tilastoalueet poikkeavat naapurialueista, joiden väestönkehitys on ollut vaihtelevampaa ja kääntynyt jo laskuun. Vuoden 1970 ennustettujen väestömäärien perusteella muutoksen suunta tulee olemaan sama viisivuotiskaudella 1965-1970.

Tutkimusalueen väestönkasvu perustuu osaksi sen korkeaan luonnolliseen väestönlisäykseen, joka tutkimusalueen kunnissa on yleensä voimakkaampi kuin muualla maassa (Aario 1960, kartta 12/12). Tällaista erikoisasemaa ei tutkimusalueella ole aina ollut, vaan se on kehittynyt ajan mittaan (Fontell 1910, kartat $4 / 27,8 / 27$ ja $3 / 28$, ja Tuder 1925, kartta 4/22).

Tutkimusalue on myös ollut vilkkaan muuttoliikkeen kohteena. Tämä on ollut sekä alueelle muuttoa että sieltä poismuuttoa ja vaihdellut suhdanteiden mukaan (Ajo 1962, 8-21, Lento 1956, 138 ja 140 ja Purola 1964, 84). Alueelle muuttanut väestö on osatekijä sen voimakkaaseen luonnolliseen väestönkasvuun, sillä muuttava työikäinen väestö on voimakkaasti lisääntyvää. Toisaalta korkea luonnollinen väestönlisäys aiheuttaa helposti väestöpainetta, jonka vaikutuksesta syntyy poismuuttoa. Tutkimusalueen jatkuvan väestönkasvun edellytyksenä ovat olleet paikalliset noususuhdanteet, kuten sodanjälkeinen jälleenrakennuskausi, johon liittyy voimalaitosten rakentaminen ja asutustoiminta. 

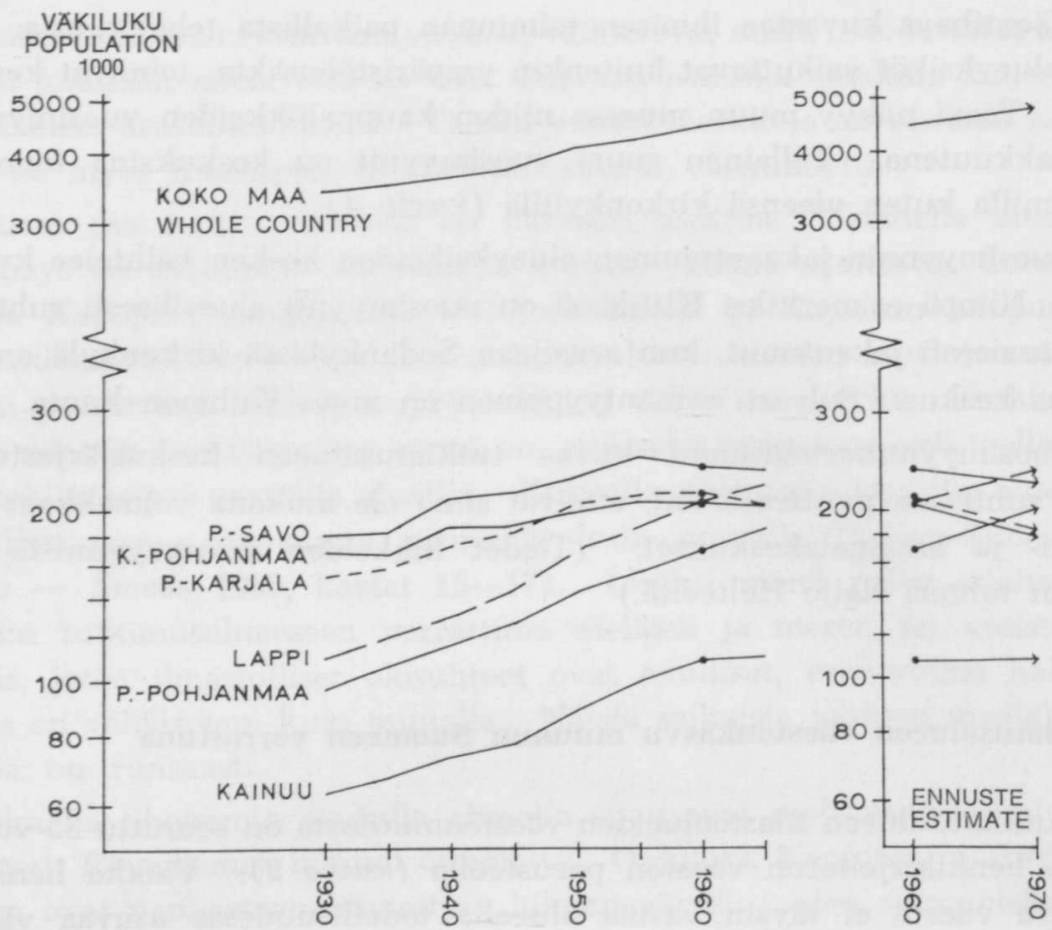

Kuvio 9. Henkikirjoitettu väestö tutkimusalueen tilastoalueilla ja naapuritilastoalueilla sekä koko maassa 1930-1970 (STV 1930 - 1965 ja Valtakunnansuunnittelutoimisto 1964).

Figure 9. Population registered in the population registers of the statistical regions of the region under investigation and the neighboring statistical regions, and in the whole country between 1930 and 1970 .

\section{Lyhytaikainen väestönmuutos tutkimusalueella}

Tutkimusalueen alueyksikköjen väestönmuutosta on seurattu vuosien 1960 ja 1964 äänioikeutettujen lukumäärien perusteella. Koska alueyksiköissä on eri määrät äänioikeutettuja, vaihtelevat väestönmuutosten tilastolliset merkitsevyydet. Väestönkasvu tai väheneminen voi syntyä esimerkiksi alueelle muuttaneiden tai sieltä muuttavien henkilöiden toisistaan riippumattomista muuttamispäätöksistä. Jos kuitenkin näihin vaikuttaa yhtenäistävä tekijä, esimerkiksi työmahdollisuudet lisääntyvät alueyksiköllä, ei satunnaisvaihtelun malli riitä selittämään väestönmuutoksen suuruutta.

Pienimmän alueyksikön äänioikeutettujen lukumäärä on 36 henkeä. Yleensä se on kuitenkin paljon suurempi, sillä mediaani on 166 henkeä. Pienimmän alueyksikön kohdalla $11 \%$ :n suuruinen muutos on merkitsevä $5 \%: n$ riskillä, mediaanialueyksikön kohdalla kuitenkin jo $7 \%$ :n muutos 
T a u lukko 1. Väestönmuutos erikokoisen taajaman sisältävissä alueyksiköissä

Table 1. Changes in the population of areal units including a nonadministrative agglomeration

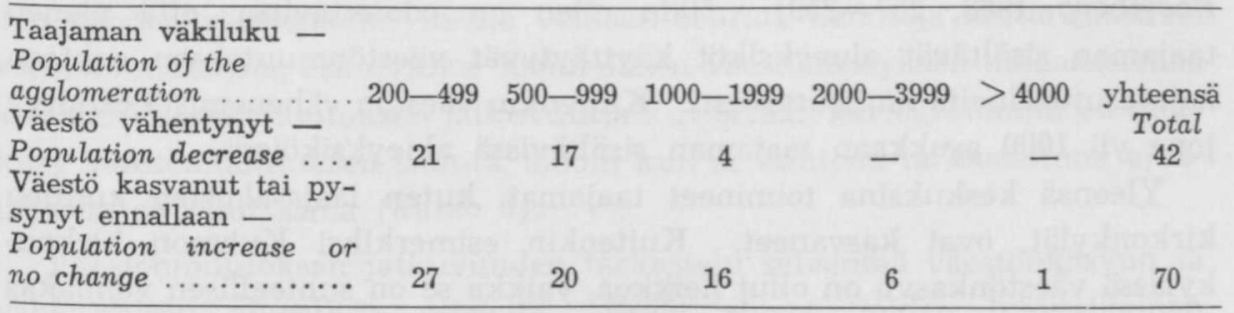

Taulukko 2. Kaupunkien äänioikeutetun väestön rakenne ja kasvu $1960-64$

Table

2. The structure and growth of the enfranchised population of cities in 1960-64

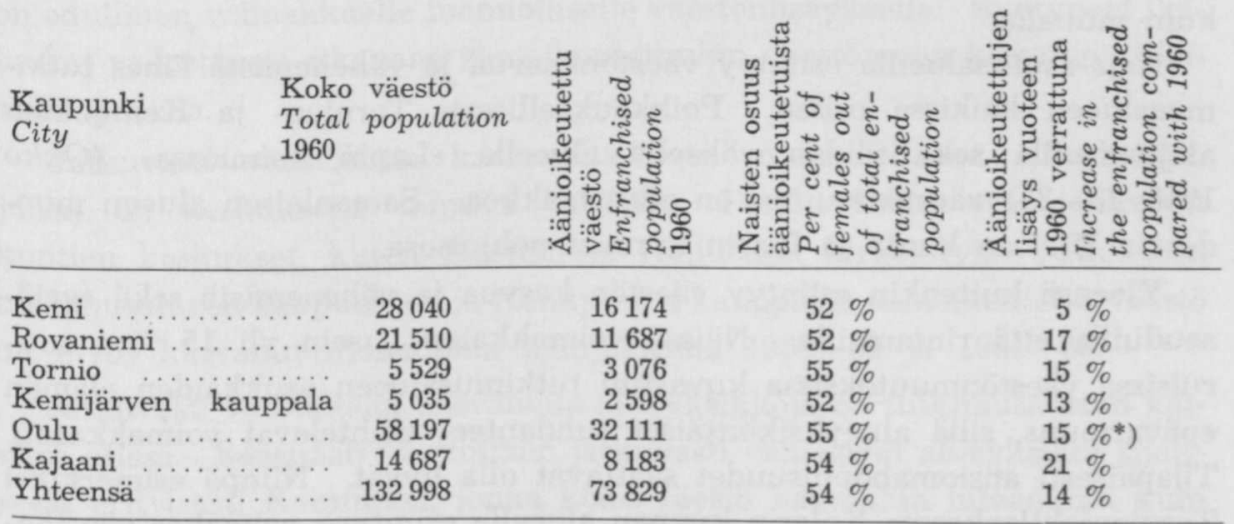

*) Prosenttiluvussa ei ole alueliitosten vaikutusta.

on merkitsevä $0.1 \%: n$ riskillä. Kartogrammin (kuvio 5) ilmaisemat 10 ja 15 prosentin muutokset ovat siis yleensä merkitseviä. Testaukset on suoritettu t-testillä.

Siitä huolimatta, että tutkimusalueen väestö on tarkasteltuna ajanjaksona kokonaisuutena kasvanut, on useimmissa haja-asutusta sisältävissä alueyksiköissä väestö vähentynyt. Näitä on 362 kokonaismäärän ollessa 651 .

Kuitenkin ne alueyksiköt, joissa on väestölaskennassa taajamaksi määritelty väentihentymä, ovat suurimmaksi osaksi kasvaneet. Väestönmuutoksen suunta riippuu jossain määrin taajaman koosta, mikä ilmenee taulukosta 1. 
Vähenevän väestön alueyksiköissä on keskimäärin pienempi taajama kuin kasvavan väestön alueyksiköissä. Koska väestölaskennassa suoritetussa taajamien määrityksessä ei ole kiinnitetty huomiota niiden elinkeinorakenteeseen, ovat pienimmät taajamat usein tavallisia maalaiskyliä (vrt. Fogelberg 1963, 257-259). Näin ollen on odotettavissa, että pienen taajaman sisältävät alueyksiköt käyttäytyvät väestönmuutoksen suhteen haja-asutusalueita muistuttavasti. Kuitenkin väestön vähenemistä esiintyy jopa yli 1000 asukkaan taajaman sisältävissä alueyksiköissä.

Yleensä keskuksina toimineet taajamat, kuten laaja-alaisten kuntien kirkonkylät, ovat kasvaneet. Kuitenkin esimerkiksi Kuhmon kirkonkylässä väestönkasvu on ollut heikkoa, vaikka se on suhteellisen voimakas keskus ainakin vähittäiskauppojen vuosimyynnin perusteella (kuvio 4). Tutkimusalueen kaupunkien äänioikeutettu väestö on yleensä kasvanut voimakkaasti, mikä ilmenee taulukosta 2.

Heikoin on väestönkasvu ollut Kemissä, jonka joidenkin äänestysalueiden väestö on jopa vähentynyt. Voimakkaimmin on kasvanut Kainuun keskus Kajaani. Tällä alueella kirkonkylien väestönkasvu oli heikompaa kuin muualla.

Haja-asutusalueilla esiintyy väestönkasvua ja vähenemistä lähes tutkimusalueen kaikissa osissa. Poikkeuksellisesti Tornion- ja Kemijokien alajuoksuilla sekä niiden välisellä alueella "Lapin kolmiossa" (Okko 1946, 13-24) väestönmuutos on ollut heikkoa. Samanlaisen alueen muodostaa Utsjoen kunta ja Inarin kunnan pohjoisosa.

Yleensä kuitenkin esiintyy väestön kasvua ja vähenemistä sekä syrjäseuduilla että rintamailla. Näissä voimakkaissa, usein yli $15 \%$ :n suuruisissa väestönmuutoksissa kuvastuu tutkimusalueen asukkaiden elämän epävarmuus, sillä alueyksiköittäiset suhdanteet vaihtelevat voimakkaasti. Tilapäisesti ansiomahdollisuudet saattavat olla hyvät. Niinpä esimerkiksi Tornionjokilaaksossa Kolarin kunnan alueella esiintyvä voimakas väestönkasvu johtuu muuttovoitosta, joka taas on aiheutunut rautatien ja maantien rakennustöistä ja Rautuvaaran kaivostoiminnan valmisteluista (Naukkarinen 1966, 11). Rautatien rakennus on ulottanut vaikutuksensa myös Pellon kuntaan, jonka pohjoisosassa väestö voimakkaasti kasvaa.

Väestönkehitykseen vaikuttavia työtilaisuuksia ovat myös voimalaitosten rakentamiset. Niihin perustuen on varsinkin Kemijokivarteen syntynyt useita taajamia, joiden väkiluku kuitenkin nyt useiden voimalaitosten valmistuttua on alkanut vähentyä. Voimalaitostöiden päättymisestä johtuu osaltaan eräiden Oulujokilaakson alueiden väestön väheneminen.

Tutkimusalueen kasvavaa väestöä on pyritty sijoittamaan myös perustamalla uusia maatiloja. Tämä aikaansaa kuntien sisäistä ja välistä muuttoliikettä näille asutusalueille. Toisaalta taas joidenkin vanhojen asutusalueiden väestö samanaikaisesti vähenee. Tällaista kehitystä esiintyy muun muassa Sallan kunnassa. 


\section{Väestönmuutoksen jatkuvuus tutkimusalueella}

Neljän vuoden ajanjaksona tutkimusalueen alueyksikköjen väestö vaihteli usein varsin voimakkaasti. Liittämällä tähän tiedot seuraavan kahden vuoden väestönkehityksestä voidaan seurata heikkoja mutta jatkuvia väestönmuutoksia, esimerkiksi luonnollisen väestönlisäyksen aikaansaamaa kasvua. Väestönmuutoksen jatkuvuutta kuvaavaan kartogrammiin on merkitty väestönmuutoksen suunta, silloin kun se kahtena tarkasteltuna ajanjaksona on ollut sama (kuvio 6).

Väestönmuutoksen jatkuvuuden tarkastelu selventää väestönkasvun ja vähenemisen alueellisia piirteitä. Eräät alueet, joiden lyhytaikainen väestönmuutos oli heikkoa, osoittautuvat väestöltään jatkuvasti kasvaviksi. Tällaisia on erityisesti Tornionjokilaaksossa ja Enontekiön ja Inarin kunnissa. Erityisen paljon on jatkuvan väestönkasvun alueyksiköitä vyöhykkeellä, joka käsittää Kuusamon kunnan pohjoispuolen, itäosan Posion ja Kemijärven maalaiskunnista sekä Sallan kunnan. Näillä seuduilla on paljon sodan jälkeen perustettuja asutusalueita, joiden väestön ikärakenne on edullinen voimakkaalle luonnolliselle väestönlisäykselle. Syntyneet ikäluokat vaikuttavat aikanaan äänioikeutetunkin väestönosan kasvuun tällaisella alueella.

Jatkuvasti väestöltään kasvaneita ovat myös sellaiset alueyksiköt, joissa on keskuksena toimiva taajama. Poikkeuksena ovat joidenkin kuntien keskukset, kuten Kittilän ja Hailuodon kirkonkylät. Kaikkien tutkimusalueen kaupunkien ja Kemijärven kauppalan äänioikeutettu väestö on myös kasvanut molempina ajanjaksoina 1960—64 ja 1964-66.

Jatkuvasti väestöltään kasvaneita alueyksikköjä on tutkimusalueen kaikissa osissa. Sensijaan väestöltään jatkuvasti vähenevät alueyksiköt sijaitsevat erityisesti Kainuussa, jonka koko väestö kasvaakin hitaammin kuin muiden tutkimusalueen tilastoalueiden (kuvio 5). Väestön jatkuvaa vähenemistä näyttää myös tapahtuvan erityisesti Kajaanin, Oulun ja Rovaniemen ympäristöissä ja niihin johtavien liikenneteiden varsilla. Kemin kaupungin ympäristössä ei kuitenkaan ole kuin muutama väestöltään jatkuvasti vähenevä alueyksikkö. Tämä saattaa johtua siitä, ettei Kemillä suhteellisen hitaasti kasvavana kaupunkina ole yhdessä pienen Tornion kanssa samaa väestön vetovoimaa kuin Oululla, Kajaanilla ja Rovaniemellä. Jatkuva väestönkasvu tai väheneminen eivät kuitenkaan yleisesti riipu tutkimusalueella etäisyydestä kaupungista, sillä jatkuvan väestönkasvun tai vähenemisen alueyksiköiden lähimmästä kaupungista tai kauppalasta mitattujen etäisyyksien perusteella muodostetut jakautumat eivät poikkea tilastollisesti merkitsevästi kaikkien alueyksiköiden etäisyysjakautumasta ( $\mathrm{X}^{2}$-testi). 


\section{Sukupuolirakenteen alueelliset piirteet}

Alueyksiköiden väestön sukupuolirakennetta on tutkittu äänioikeutetun väestön perusteella (kuvio 7). Syrjäseuduilla naisten osuus äänioikeutetuista vaihtelee paikoitellen $42-50 \%$. Näinkään suuri vaihtelu ei kuitenkaan välttämättä kuvasta oleellisia eroja vierekkäisten alueyksikköjen olosuhteissa. Odotusarvona maaseudulla voidaan pitää $46 \%$. Neljänkin prosenttiyksikön poikkeama tästä voi mediaaniväestöisen alueyksikön kohdalla johtua satunnaisista syistä (t-testi).

Vaikka paikalliset vaihtelut eivät välttämättä ole merkitseviä, on väestön sukupuolirakenteen jakaantumisessa selvä alueellinen säännönmukaisuus. Naisten suhteellinen lukumäärä on suurimmillaan kaupungeissa (taulukko 2) ja yleensäkin rintamailla, tutkimusalueen tiheään asutuissa osissa. Sensijaan syrjäseuduilla on voimakas miesenemmistö. Tällainen vaihtelu esiintyy myös yleensä kuntien sisällä, kirkonkylissä naisten osuus äänioikeutetuista on $46-50 \%$, mutta kuntien reunaosissa alle $46 \%$.

Samanlainen ero toisaalta taajamien ja haja-asutusalueiden, toisaalta rintamaiden ja syrjäseutujen välillä on olemassa myös ilmiötä koko maan puitteissa tarkasteltaessa. Alameri on käsitellyt koko väestön sukupuolijakautumaa vuosina 1910-1950. Hän toteaa muun muassa, että maaseudun taajamissa on tilastollisesti erittäin merkitsevästi enemmän naisia kuin taajamien ulkopuolisella alueella (Alameri 1960, 39). Rintamaiden ja syrjäseutujen välinen vastakohtaisuus taas ilmenee koko maan puitteissa siten, että pohjoisosissa ja koillisissa maalaiskunnissa on tilastollisesti merkitsevä miesenemmistöisyys. Tutkimusalue kokonaisuutena käsittää suurimman osan tällaisista maalaiskunnista vuonna 1950, ja kuten luonnollisen väestönlisäyksen kohdalla sen erikoisasema on tässäkin suhteessa ajan mittaan korostunut (Alameri 1960, 40-41). Alameren viimeisin aineisto on vuodelta 1950 , mutta samat eroavuudet vallitsevat myös vuonna 1960 . Naisia oli silloin maaseudun ei-hallinnollisissa taajamissa $52,2 \%$ väestöstä, kun heitä varsinaisella maaseudulla oli 49,5\%. Tutkimusalueen tilastoalueilla oli myös naisten osuus koko väestöstä $1-2$ prosenttiyksikköä alhaisempi kuin koko maassa (SVT VI C: 103 II, taulu 1).

Naisten vähemmyys syrjäseuduilla johtunee pääasiassa siitä, että heidän työmahdollisuutensa ovat siellä huonommat kuin rintamailla. Niinpä kuntien keskustaajamissa palveluammatit tarjoavat naisille työtilaisuuksia, kun sensijaan muissa osissa vallitsevat yleensä maatalouden lisäksi vain miespuolista työvoimaa enemmälti käyttävät elinkeinot kuten metsätalous (vrt. Naukkarinen 1966, 18).

\section{Oppivelvollisten suhteellisen lukumäärän alueellinen vaihtelu}

Tutkimusalueen väestön ikärakennetta on tarkasteltu vertaamalla alueyksikön oppivelvollisten lukumäärää äänioikeutettujen lukumäärään (kuvio 8). Sattuman osuus tämän suhdeluvun vaihteluissa on suurin piirtein 
sama kuin naisten osuuden kohdalla, joten tässäkään eivät vierekkäisten alueyksikköjen erot välttämättä johdu eroavuudesta jonkin määrätyn alueyksikköjen ikärakenteeseen vaikuttavan ekologisen tekijän suhteen.

Väestön ikärakenteessa ei esiinny tutkimusalueella sellaisia suuria alueellisia säännönmukaisuuksia kuin väestön sukupuolirakenteen kohdalla. Esimerkiksi alueyksikköjä, joissa oppivelvollisia on paljon, on sekä kuntien keskeisillä että niiden syrjäisillä alueilla. Toisaalta on alueita, joilla oppivelvollisten suhde äänioikeutettuun väestöön vaihtelee alueyksiköittäin vähän. Lapin läänin pohjoisosassa on paljon alueyksiköitä, joissa oppivelvollisten lukumäärä on verrattain pieni. Melkein yhtenäinen ketju tällaisia alueyksiköitä on myös tutkimusalueen länsireunassa ja Pohjanlahden rannikolla. Niinpä muun muassa Tornion ja Kemin kaupunkien suhteellisen tiheään asutussa ympäristössä on yleensä alueyksiköissä vähän oppivelvollista väestöä. Tällainen alue jatkuu Kemijoen vartta Rovaniemelle ja sen ympäristöön. Sama piirre on myös Oulun ja Kajaanin ympäristöalueilla.

Yleispiirteenä näyttää oppivelvollisten osuus kuvastavan alueyksikön asutuksen ikää siten, että se on usein suuri suhteellisen äskettäin asutetuilla alueilla. Vanhinta asutusta, jossa oppivelvollisia on yleensä vähän, on toisaalta pohjoisimmissa kunnissa, saamelaisväestön alueella, toisaalta Tornionjoen, Kemijoen ja Oulujoen suupuolilla sekä niiden ja niihin liittyvien vesistöjen varsilla. Uusi asutus on sijoittunut suurimmaksi osaksi näiden alueiden ulkopuolelle. Toisaalta vanhankin asutuksen alueella on uusia asutuskerrostumia kuten kasvavia palvelukeskuksia ja teollisuustaajamia.

\section{Väestöllisten ilmiöiden riippuvuussuhteet}

Alueyksikköjen ekologisia olosuhteita kuvaavien muuttujien avulla voidaan tilastollisilla menetelmillä tutkia väestönrakenteen ja väestönmuutoksen yleisiä riippuvuussuhteita, niinkuin jo on tehtykin selviteltäessä väestönmuutoksen jatkuvuuden riippuvuutta etäisyydestä kaupungista. Tutkimusalueen kaupungit ja kauppala ovat voimakkaita keskuksia (Lapin läänin taajamat 1963 ja Tuominen 1953). Niinpä muuttujaa nimitetään keskusetäisyydeksi. Se on mitattu maantiematkana ja siitä käytetään logaritmimuunnosta. Tämän etäisyysmuuttujan lisäksi on määritetty maantiematka alueyksikön väestöllisestä painopisteestä kunnan keskukseen. Kunnan keskuksena taas on pidetty paikkaa, jossa sen virastot sijaitsevat. Tämä on yleensä kirkonkylä.

Riippuvuussuhteet on mitattu Pearsonin tulomomenttikorrelaatiokertoimella. Aluetta havaintoyksikkönä käytettäessä ovat kuitenkin muuttujien jakautumat vain poikkeustapauksissa normaalijakautumia, mitä edellä mainitun korrelaatiokertoimen käyttö niiltä edellyttäisi. Siitä huolimatta tämä korrelaatiokerroin kuvastaa ilmiöiden välisiä yhteisvaihteluita, joten saa- 
$\mathrm{T} \mathrm{a} \mathrm{u} \mathrm{l} \mathrm{u} \mathrm{k} \mathrm{k} \mathrm{o} \mathrm{3.} \mathrm{Väestöllisten} \mathrm{muuttujien} \mathrm{korrelaatiot} \mathrm{haja-asutusalueilla}$ Table

3. Correlations of population variables in sparsely inhabited areas

$n=651$

\begin{tabular}{cccccccc}
$\mathrm{n}=651$ \\
\hline 1 & 2 & 3 & 4 & 5 & 6 \\
\hline
\end{tabular}

1) Oppivelvollisia \% äänioikeutetuista - Per cent of school age of enfranchised population .................. 2) Aänioikeutetut naiset \% miehistä - Per cent of enfranchised females of male population ................ 3) Miesten lisäys \% - Increase in males per cent .... 4) Naisten lisäys \% - Increase in females per cent.. 5) Etäisyys kunnan keskustasta - Distance from center of commune .................

6) Etäisyys suurkeskuksesta

7) Väentiheys - Density of population

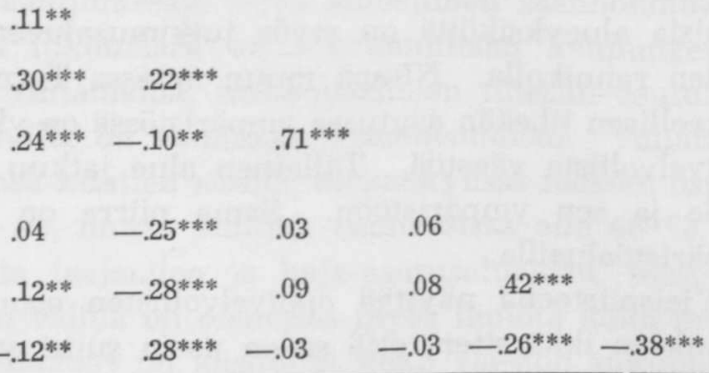

** Korrelaatiokerroin merkitsevä, riski $1 \%$ Correlation significant at .01 level

*** Korrelaatiokerroin erittäin merkitsevä, riski $0.1 \%$ Correlation significant on .001 level

duilla luvuilla on merkitystä. Niiden vertaaminen satunnaisvaihtelun malliin on kuitenkin vaikeaa, sillä tavanmukaiset testausmenettelyt edellyttävät normaalijakautumia. Silti korrelaatiokerrointen merkitsevyys on ilmaistu tavanmukaisella tavalla, jolloin riski ilmoittaa, kuinka suurella todennäköisyydellä laskettu korrelaatio voi syntyä useiden toisistaan riippumattomien tekijäin vaikutuksesta (testaus Fisherin z-muunnoksen avulla). Paras tapa korrelaatiokerrointen yleisen merkitsevyyden tarkastelussa on kuitenkin tutkia kerrointen arvoja eri aineistoissa. Tämän vuoksi ja koska ilmeni, että korrelaatioiden suunnat vaihtelevat, aineisto on jaettu kolmeen analyysiyksikköön.

Alueyksikköjen jako on ensinnäkin suoritettu niiden asutuksen muodon perusteella. Ne alueyksiköt, joissa on väestönlaskennassa taajamaksi määritelty väentihentymä, on käsitelty omana ryhmänään. Taajaman sisältävät alueyksiköt on vielä jaettu kahteen osaan väestönmuutoksen suunnan perusteella, jolloin toiseen ryhmään kuuluvat ne alueyksiköt, joiden väestö on vähentynyt, ja toiseen ne, joiden väestö on kasvanut tai pysynyt muuttumattomana. Vaikka taajaman sisältävissä alueyksiköissä on muutakin kuin taajamaväestöä, tämä käsittää kuitenkin niin suuren osan niiden väestöstä, että alueyksiköt hyvin kuvaavat myös itse taajamia.

Useimmat taajamat sijaitsevat tutkimusalueen rintamaisissa osissa, joissa väentiheys on suuri. Keskukset taas voidaan erottaa suuren vuosimyynnin perusteella (kuviot 3 ja 4). 
Ta ulukko 4. Väestöllisten muuttujien korrelaatiot taajama-alueilla väestönmuutoksen perusteella jaetussa aineistossa

Table

4. Correlations of population variables in agglomerated areas for data divided according to type of population change

Kasvavan väestön aineisto ylemmällä rivillä, $\mathrm{n}=71$

Data for growing population in upper row, $n=71$

Vähenevän väestön aineisto alemmalla rivillä, $n=41$

Data for decreasing population in lower row, $n=41$

$\begin{array}{llllll}1 & 2 & 3 & 4 & 5 & 6\end{array}$

1) Oppivelvolliset \% äänioikeutetuista - Per cent of school age of

enfranchised population ...........

2) Aänioikeutetut naiset \% miehistä - Per cent of enfranchised females of male population ......... 3) Miesten lisäys \% - Increase in

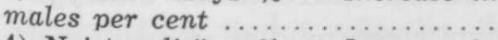
4) Naisten lisäys \% - Increase in females per cent ................

5) Etäisyys kunnan keskuksesta -

Distance from center of commune

6) Etäisyys suurkeskuksesta - Dis-

tance from major center ..........

7) Taajaman väkiluku - Popula-

tion of the non-administrative $\begin{array}{ccccccc}-.23 & .21 & .40^{* *} & .40^{* *} & -.34^{* *} & .05\end{array}$

\begin{tabular}{l} 
agglomeration $\quad \ldots \ldots \ldots \ldots \ldots \ldots \ldots \ldots$ \\
\hline
\end{tabular}

** Korrelaatiokerroin merkitsevä, riski $1 \%$

Correlation significant at .01 level

*** Korrelaatiokerroin erittäin merkitsevä, riski .001\%

Correlation significant at .001 level

Etäisyys suurkeskuksesta ja etäisyys kunnan keskuksesta riippuvat väestön sijoittumisesta johtuvista syistä toisistaan (taulukko 3). Yleensä suurkeskuksen puoleisessa osassa kuntaa on tiheämpi asutus kuin muualla ja tästä johtuen kunnan keskus sijaitsee siellä. Joissakin tapauksissa kuten Rovaniemen ja Kemijärven maalaiskuntien kohdalla kunnan virastot sijaitsevat itse suurkeskuksessa. Väentiheysmuuttujan korrelaatiot etäisyyteen taas johtuvat siitä, että keskukset kehittyvät tiheän asutuksen alueille, joten niistä etäännyttäessä väentiheys yleensä pienenee. Ekologisten muuttujien korreloinnista johtuen voidaan niiden vaikutus yhdistää ja puhua niiden kuvastamasta yhteisestä tekijästä, syrjäisyydestä. Tämä vaikuttaa myös muihin alueyksikköjen ominaisuuksiin, kuin mitä tässä on käsitelty (Pesonen 1966, 11).

Ekologisten muuttujien vaikutuksen yhdistäminen ei kuitenkaan ole mahdollista taajaman sisältämistä alueyksiköistä muodostetuissa aineistoissa, sillä ne eivät niissä korreloi selvästi keskenään. Näissä aineistoissa on myös väentiheyden sijasta käytetty sitä riippuvuussuhteiltaan muistuttavaa, mutta merkitykseltään selvempää muuttujaa taajaman väkiluku (taulukko 4). Väentiheys ja väestölliset muuttujat ovat samoja kuin 
mitä edellä alueellisissa tarkasteluissa on käytetty. Väestönmuutosta on kuitenkin käsitelty erikseen miesten ja naisten kohdalta.

Seuraavassa viitataan vain korrelaatiomatriisien pääpiirteisiin. Muuttujien väliset korrelaatiot eivät välttämättä edellytä niiden välillä vallitsevan tosiasiallista riippuvuussuhdetta, vaan niiden yhteisvaihtelu voi johtua samasta molempiin vaikuttavasta ekologisesta tekijästä.

Taajama-alueilla on vähemmän tilastollisesti merkitseviksi ilmoitettuja korrelaatioita, sillä satunnaisuuden osuus muuttujien vaihteluista saattaa tässä aineistossa olla suurempi. Toisistaan riippumattomien aineistojen avulla voidaan kuitenkin arvioida samansuuntaisten korrelaatioiden yleistä merkitsevyyttä. Sensijaan riippuvuussuhteiden erot voivat johtua tutkimusalueeseen liittyvistä erikoisista olosuhteista.

Sukupuolirakenteen ja oppivelvollisten osuuden korrelaatiot etäisyysja väentiheysmuuttujiin ilmaisevat samat yleispiirteet näiden väestöllisten muuttujien vaihteluissa, kuin mitä havaittiin niiden alueellisia piirteitä tarkastelemalla. Naisten osuushan pieneni ja oppivelvollisten osuus kasvoi syrjäisyyden lisääntyessä. Korrelaatioiden perusteella tämä riippuvuussuhde varsinkin ikärakenteen kohdalla on kokonaisuutena heikko. Väestönmuutoksella ei sensijaan näyttänyt olevan riippuvuutta syrjäisyydestä, eikä sillä olekaan korrelaatioita etäisyyteen tai väentiheyteen haja-asutusalueella. Taajama-alueilla miesten muutos näyttää riippuvan etäisyydestä kunnan keskuksesta, sillä miespuolisen väestön vähennys on yleensä pienempi etäisyyden ollessa suuri ja vastaavasti lisäys on suurempi kuin lähellä kunnan keskusta. Korrelaatio väestön lisäykseen on tosin heikko. Taajaman koolla on jonkinverran vaikutusta sekä miesten että naisten muutokseen.

Miesten ja naisten muutokset korreloivat keskenään haja-asutusalueilla. Samat väestönmuutokseen vaikuttavat tekijät vaikuttavat kummankin sukupuolen kohdalla samansuuntaisesti. Niinpä väestön lisäys on sitä suurempi, mitä suurempi on oppivelvollisen väestön osuus. Tällainen väestön muutoksen ja sen ikärakenteen yhteenkuuluvuus johtuu uuden asutuksen kasvusta, jolle on muun muassa ominaista oppivelvollisten ikäluokkien runsaus.

Toisaalta väestön sukupuolirakenne liittyy myös sen muutoksen vaihteluihin. Korrelaatio on kuitenkin erisuuntainen miesten ja naisten lisäyksen kohdalla. Sukupuolirakenteella on siis naisten muutokseen jossain määrin toisenlainen vaikutus kuin miesten muutokseen, siitä huolimatta että kummankin sukupuolen muutokset korreloivat keskenään ja samalla tavoin oppivelvollisten ikäluokkien osuuteen. Tämän aikaansaavan ekologisen tekijän vaikutus on erityisen selvä vähenevän väestön taajamaalueella, mutta puuttuu kasvavan väestön alueelta, jossa eri sukupuolten muutokset korreloivat voimakkaasti keskenään. Tällöin tietenkin tällaisen 
vaihtelukomponentin osuus ei voi olla voimakas. Taajama-aineiston korrelaatiot poikkeavat väestön kasvun ja vähenemisen alueilla miesten muutoksen kohdalla, jolloin lisäys korreloi positiivisesti taajaman väkilukuun, mutta vähennysprosentti on myös sitä suurempi, mitä suurempi on taajaman väkiluku.

\section{Ikäryhmien suuruuksien ja niiden sukupuolirakenteen väliset korrelaatiot}

Väestön ikä- ja sukupuolirakenteen välisiä riippuvuussuhteita on edellä tutkittu oppivelvollisen ja äänioikeutetun väestönosan perusteella. Väestön ryhmittely oppivelvollisiin ja äänioikeutettuihin on kuitenkin varsin karkea jako. Kun osasta tutkimusaluetta on ollut käytettävissä alueyksiköittäin tiedot väestön ikärakenteesta viiden ikäryhmän perusteella ja kun samat tiedot on voitu kerätä myös tutkimusalueen taajamista vuoden 1960 väestönlaskennan perusteella, on voitu selvitellä tarkemmin ikäryhmien suuruussuhteiden ja niiden sukupuolirakenteen välisiä riippuvuussuhteita.

Aineisto on kahdenlaista. Toisaalta siihen kuuluvat tutkimusalueelta näytteenä olevien kuntien alueyksiköt ja toisaalta kaikki tutkimusalueen taajamat, jotka ovat myös pieniä alueellisia kokonaisuuksia. Näytekuntien väestön tutkiminen perustuu vuosien 1963-64 henkikirjoihin, ja tiedot ovat niin ollen toisenlaisesta lähteestä kuin taajamien vuoden 1960 väestönlaskentaan perustuvat tiedot. Taajamiin kuuluvat tietenkin myös näytekunnissa sijaitsevat taajamat, mutta niitä on siksi vähän, että aineistoja voidaan pitää käytännöllisesti katsoen toisistaan riippumattomina.

Näytekunnat ovat kuviossa 10, jossa ovat lisäksi varsinaisen tutkimusalueen ulkopuolelta Nurmeksen ja Juuan kunnat, jotka eivät ole mukana aineiston tilastollisessa käsittelyssä. Näytekunnat ovat suhteellisen harvaan asuttuja ja suuria. Niiden henkikirjoitettu väestö oli 1.1.1964 yhteensä 83854 (STV 1964, taulu 14). Taajamien yhteenlaskettu väestö taas oli vuoden 1960 väestönlaskennan mukaan 224907 (SVT VI C: 103 II, taulu 1). Niissä on mukana tutkimusalueen kaupunki- ja kauppalataajamat, jotka puuttuivat aikaisemmin käsitellyistä taajaman sisältävistä alueyksiköistä.

Ikäryhmien miesten ja naisten lukumäärien perusteella muodostettiin niitä kuvaamaan neljä muuttujaa:

- ikäryhmä \% koko väestöstä - ikäryhmän osuus

- ikäryhmän miehet \% kaikista miehistä - miesten osuus

- ikäryhmän naiset \% kaikista naisista - naisten osuus

- ikäryhmän naiset \% ikäryhmän koko väestöstä - sukupuolijako. 

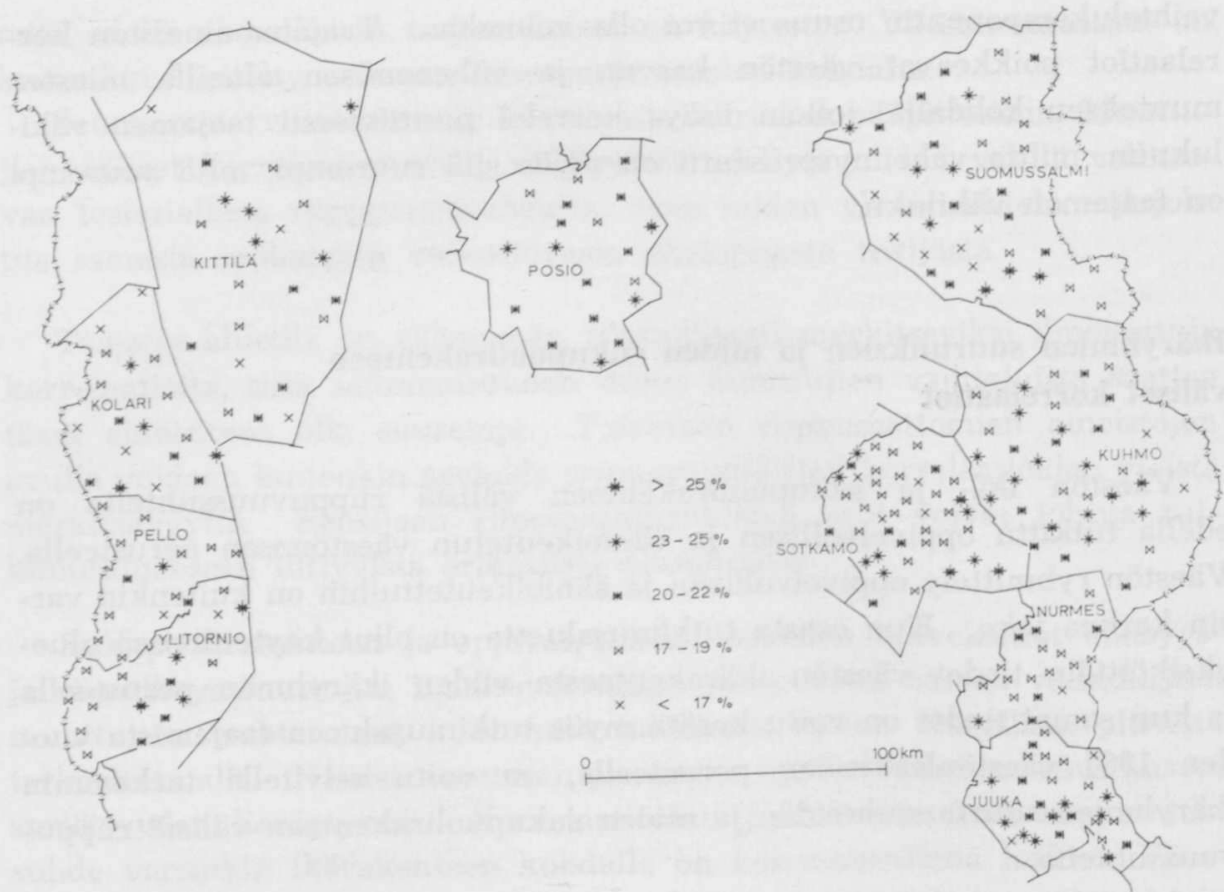

K u vi o 10. 15-24-vuotiaiden osuus väestöstä 1964 .

Figure 10. Proportion of population between the ages of 15-24 years out of the total population, 1964.

Ikäryhmät ja niiden osuuksien alueyksiköittäiset keskiarvot ovat seuravan asetelman mukaiset:

\begin{tabular}{|c|c|c|c|}
\hline & ikäryhmä & näytekunnat & taajamat \\
\hline 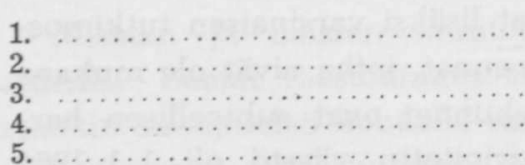 & $\begin{array}{r}0-14 \\
15-24 \\
25-44 \\
45-64 \\
<64\end{array}$ & $\begin{array}{r}33 \% \\
20 \% \\
24 \% \\
17 \% \\
7 \%\end{array}$ & $\begin{aligned} & 38 \% \\
& 15 \% \\
& 27 \% \\
& 15 \% \\
& 5 \%\end{aligned}$ \\
\hline
\end{tabular}

Koska vanhimmissa ikäryhmissä on vähemmän väestöä kuin muissa, on niiden perusteella muodostettujen muuttujien satunnaisvaihtelu myös voimakkaampaa.

Ikäryhmien suuruussuhteet ja niiden sukupuolirakenne riippuvat yhteisistä ekologisista tekijöistä. Näin ollen niiden ominaisuuksien vaihtelut seuraavat jossakin määrin toisiaan, mikä ilmenee korrelaatioina ikäryhmiä kuvaavien muuttujien välillä. Mitä voimakkaampia ovat korrelaatiot, ja mitä useammat muuttujat seuraavat toistensa vaihteluita, sitä voimakkaammin riippuvat eri ikäryhmien väestölliset ominaisuudet samoista ekologisista tekijöistä. Tietenkin väestönosien välillä voi olla myös suoranaisia vaikutussuhteita. 
Väestöllisten tekijäin riippuvuussuhteita on tarkasteltu korrelaatiolaskennan avulla. Käytetyillä muuttujilla on muodostamistavasta johtuvia ja muita teknisluontoisia riippuvuussuhteita. Näiden takia ei ole käytetty tavallista korrelaatiolaskentaa pitemmälle meneviä tilastollisia menetelmiä. Ne edellyttäisivät myös, että suhdelukumuuttujien rinnalla käytettäisiin ikä- ja sukupuoliryhmiin kuuluvien henkilöiden absoluuttisia lukumääriä variaabeleina.

Esimerkkinä ikäryhmien osuuksien suoranaisesta riippuvuudesta ekologisista tekijöistä tarkastellaan seuraavassa näytekunta-aineiston puitteissa ikäryhmien osuuksien korrelaatioita keskusetäisyyteen. Nämä ovat eri ikäryhmien kohdalla

$\begin{array}{lllll}1 . & 2 . & 3 . & 4 . & 5 . \\ .10 & .04 & .23^{* *} & -.41^{* * *} & -.25^{* * *}\end{array}$

Korrelaatioiden merkitsevyydet tarkoittavat samaa kuin taulukoissa 3 ja 4 .

Korrelaatioiden perusteella väestön ikärakenteeseen vaikuttaa näytekuntien alueilla etäisyys suurkeskuksista. Vanhimpien ikäluokkien osuudet yleensä pienenevät ja nuorimpien kasvavat syrjäseuduille siirryttäessä. Tämä johtuu näytekuntien kohdalla niin kuin koko tutkimusalueella siitä, että uudet asutusalueet on yleensä perustettu aikaisemmin raivattujen rintamaiden ulkopuolelle.

Heikoin on keskusetäisyyden korrelaatio 15-24-vuotiaiden osuuteen. Tämä ei kuitenkaan merkitse sitä, että riippuvuutta ei olisi, se vain ei ole korrelaatiokertoimen edellyttämällä tavalla lineaarinen ja sama kaikkialla tutkimusalueella. Kuviossa 10 on 15-24-vuotiaiden osuus alueyksiköittäin, jolloin mukana on myös kaksi kuntaa tutkimusalueen ulkopuolelta, jotka eivät ole vaikuttaneet korrelaatiokertoimen arvon muodostumiseen. Näiden kuntien, Juuan ja Nurmeksen maalaiskunnan sekä Sotkamon ja Tornionjokilaakson kuntien vanhoilla ja suhteellisen tiheään asutuilla rintamailla ikäryhmän osuus on yleensä pieni. Kuntien syrjäisemmissä osissa taas on suhteellisen paljon sellaisia alueyksiköitä, joiden väestöstä 15-24vuotiaiden osuus on suuri. Tällainen riippuvuus syrjäisyydestä, jota korostaa vielä se, että edellä asetelman mukaan taajamissa ikäryhmän osuus on myös keskimäärin pienempi kuin näytekuntien alueyksiköissä, ei kuitenkaan vallitse kaikissa tutkimusalueen kunnissa. Esimerkiksi Kuhmossa sellaisia alueyksiköitä on kunnan kaikissa osissa.

Ikäryhmäjaon perusteella muodostettujen muuttujien korrelaatiot ovat taulukoissa 5 ja 6 . Seuraavassa käsitellään vain eräitä korrelaatioiden syntyyn vaikuttavia tekijöitä ja matriisien rakenteen pääpiirteitä selostamatta erikseen kaikkia havaittavissa olevia riippuvuussuhteita.

Koska jonkin ikäryhmän runsaus vähentää toisten osuuksia, on ikäryhmien osuuksien kesken teknistä negatiivista korrelaatiota. Poikkeukset tästä osoittavat, että ikäryhmien runsaussuhteet seuraavat toistensa vaihteluita. Tällaista yhteisvaihtelua syntyy Eilert Sundtin lain vaiku- 


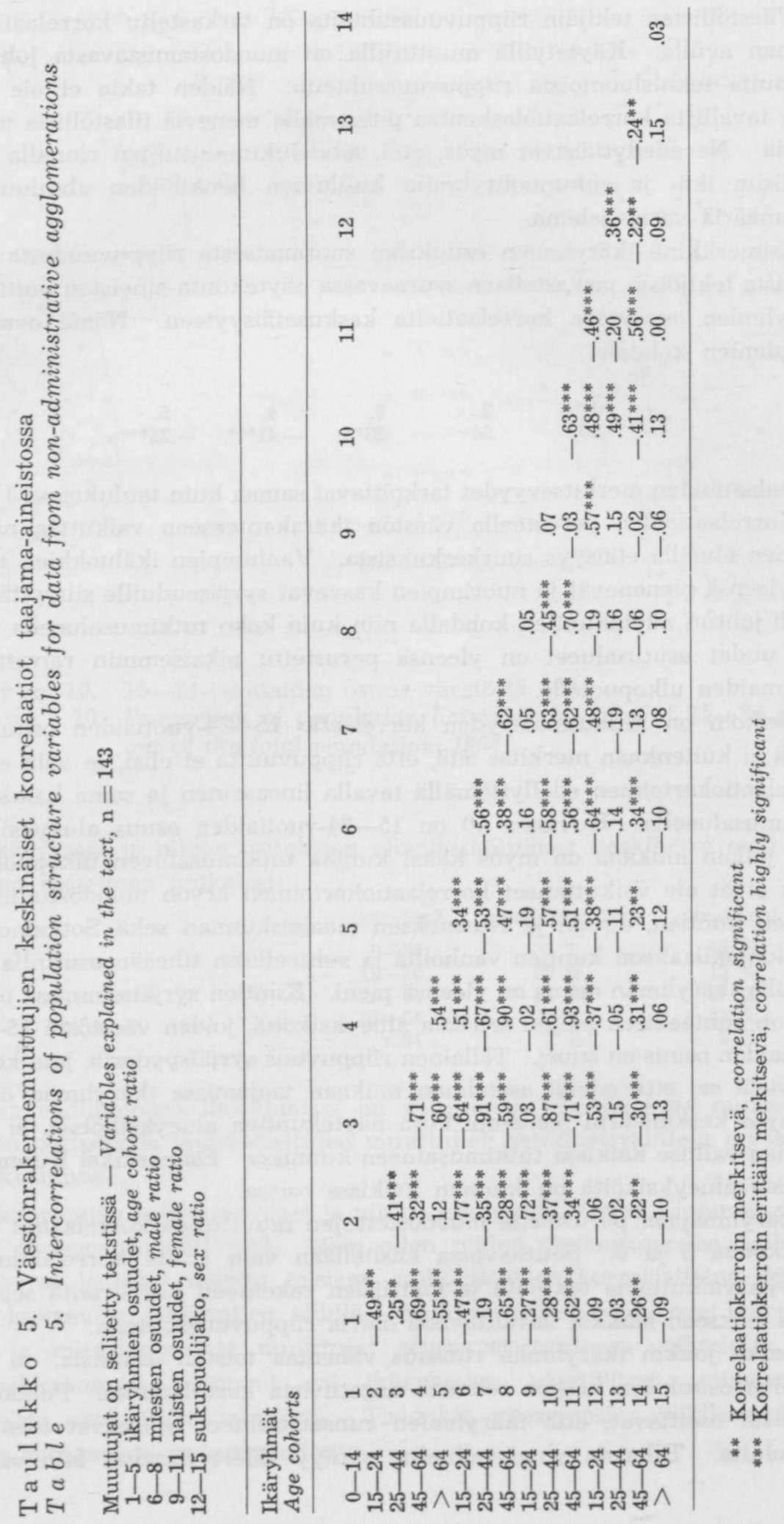




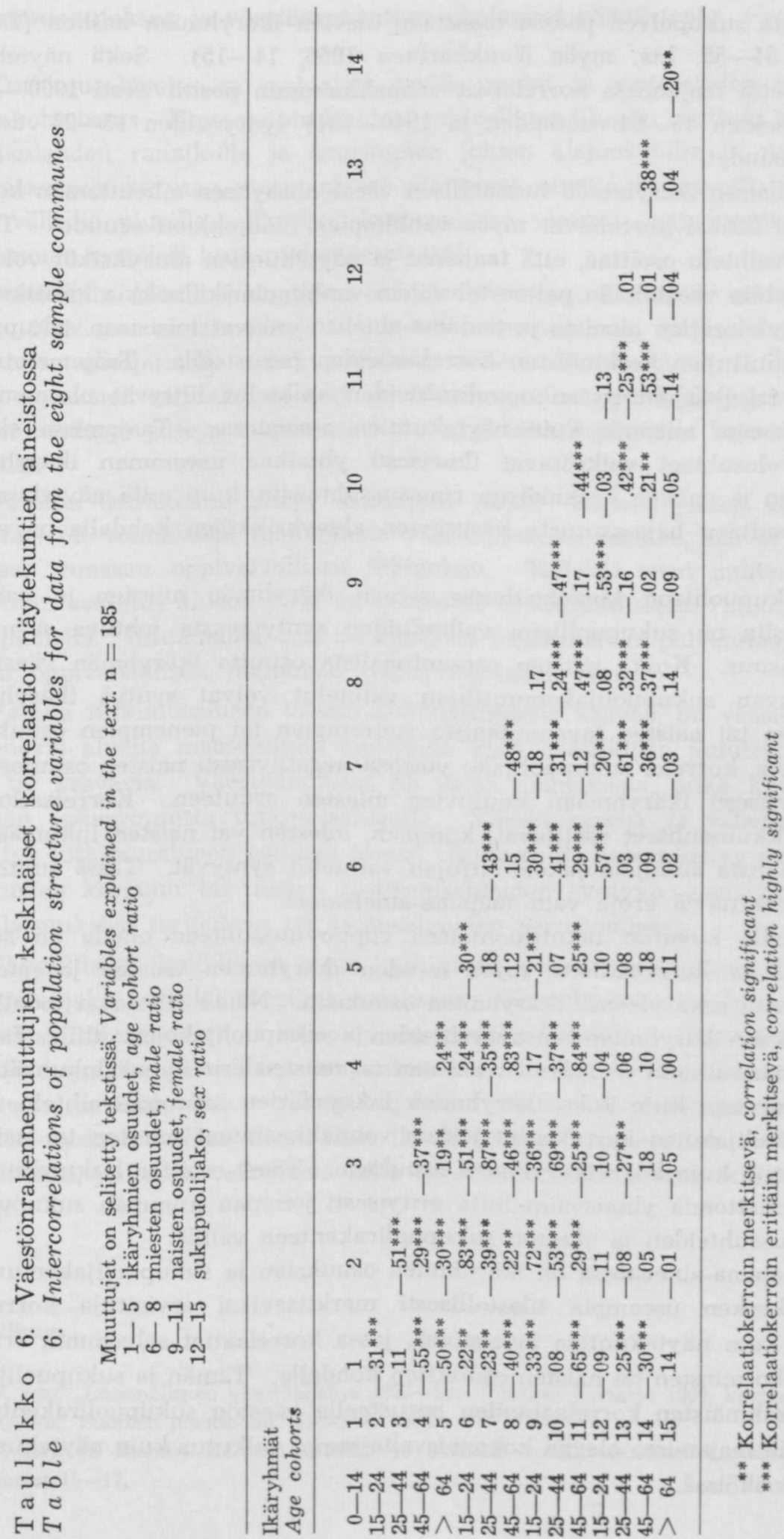


tuksesta sukupolven päässä toisistaan olevien ikäryhmien kesken (Lento 1956, 54-55, kts. myös Naukkarinen 1966, 14-15). Sekä näytekunnissa että taajamissa korreloivat voimakkaimmin positiivisesti $1900-1919$ syntyneiden 45-64-vuotiaiden ja 1940-1949 syntyneiden 15-24-vuotiaiden osuudet.

Tällaisen ikäryhmien luonnollisen väestönlisäyksen aiheuttaman korrelaation lisäksi korreloivat myös vanhimpien ikäluokkien osuudet. Tämä yhteisvaihtelu osoittaa, että taajamat ja näytekuntien alueyksiköt voidaan luonnehtia väestöltään paljon tai vähän vanhimpia ikäluokkia käsittäviksi.

Näytekuntien aineisto ja taajama-aineisto eroavat toisistaan sukupuolijakomuuttujien keskinäisten korrelaatioiden perusteella. Taajama-aineistossa eri ikäryhmien sukupuolisuhteiden vaihtelut liittyvät useammassa tapauksessa toisiinsa kuin näytekuntien aineistossa. Taajamissa ekologiset olosuhteet vaikuttavat ilmeisesti yhtaikaa useamman ikäryhmän miesten ja naisten keskinäisiin runsaussuhteisiin, kuin mitä näytekuntien valtaosaltaan haja-asutusta käsittävien alueyksikköjen kohdalla on asian laita.

Sukupuolijaon korrelaatioissa saman ikäryhmän miesten ja naisten osuuksiin on sukupuolijaon vaihteluiden syntytavasta johtuva säännönmukaisuus. Koska naisten prosentuaalista osuutta ikäryhmän väestöstä mittaavan sukupuolijakomuuttujan vaihtelut voivat syntyä ikäryhmän miesten tai naisten tavanmukaista suurempien tai pienempien osuuksien johdosta, korreloi sukupuolijako yleensä negatiivisesti naisten osuuteen ja positiivisesti ikäryhmään kuuluvien miesten osuuteen. Korrelaatioiden voimakkuussuhteet osoittavat, kumpien, miesten vai naisten lukumäärien vaihteluista sukupuolijakomuuttujan vaihtelut syntyvät. Tässä suhteessa on merkittäviä eroja vain taajama-aineistossa.

Edellä kuvatun teknisluontoisen riippuvuussuhteen ohella on sukupuolijaolla korrelaatioita myös muiden ikäryhmien naisten ja miesten osuuksiin sekä yleensä ikäryhmien osuuksiin. Nämä viittaavat todellisiin yhteyksiin ikäryhmien runsaussuhteiden ja sukupuolijakojen välillä. Vaikka satunnaisvaihtelu ikäryhmien miesten tai naisten eritellyissä lukumäärissä on suurempi kuin koko ikäryhmien lukumäärien satunnaisvaihtelu, ovat sukupuolijakojen korrelaatiot joskus voimakkaammat miesten tai naisten osuuksiin kuin koko ikäryhmien osuuksiin. Tämä osoittaa laskuteknisesti riippumattomia yhteisvaihteluita erityisesti jomman kumman sukupuolen runsaussuhteiden ja väestön sukupuolirakenteen välillä.

Taajama-aineistossa on ikäryhmien osuuksien ja sukupuolijakomuuttujien kesken useampia tilastollisesti merkitseviksi arvioituja korrelaatioita kuin näytekuntien aineistossa, jossa korrelaatiot selvemmin eriytyvät joko miesten tai naisten osuuksien kohdalle. Tämän ja sukupuolijakojen keskinäisten korrelaatioiden perusteella väestön sukupuolirakenteella näyttää taajamissa olevan kokonaisvaltaisempi vaikutus kuin näytekuntien alueyksiköissä. 


\section{Väestönmuutoksen ja väestönrakenteen ekologiset pääpiirteet}

Tutkimusalueelle on ominaista syrjäseutujen ja rintamaiden jyrkkä vastakohtaisuus. Rintamaihin kuuluu suhteellisen tiheään asuttuja alueita Pohjanlahden rannikolla ja suurimpien jokien alajuoksuilla ja varsilla. Syrjäisemmät harvaan asutut alueet sijaitsevat suurjokien latvoilla ja niiden välisillä alueilla. Kuntien keskusalueet yleensä ovat luonteeltaan vähemmän syrjäisiä kuin niiden reunaosat.

Selvimmin näistä ekologisista olosuhteista riippuu väestön sukupuolijako. Naisia on rintamailla ja taajamissa enemmän kuin syrjäseuduilla ja taajamien ulkopuolella. Sukupuolijaon vaihteluilla on myös eri ikäryhmien osuuksien vaihteluihin sekä eri ikäryhmien sukupuolijakojen vaihteluihin tiiviimpi yhteys taajamissa kuin näytteeksi tutkituilla haja-asutusalueilla.

Väestön ikärakenne liittyy asutuksen ikään. Alueet, joiden väestön rakenne on voimakasta luonnollista väestönlisäystä suosiva, saavat ajanmittaan runsaan oppivelvollisen ikäluokan. Tällaisia ovat suhteellisen äskettäin asutetut alueet, joita on runsaasti tutkimusalueella rintamaiden ulkopuolella. Rintamailla taas on kasvavia teollisuus- ja palvelutaajamia, joissa oppivelvollisen ikäluokan osuus on usein suuri.

Vaikka tutkimusalueen väestö kokonaisuutena kasvaa, on väestöltään väheneviä alueita maaseudulla enemmän kuin väestöltään muuttumattomia tai kasvavia. Väestönmuutos on usein voimakasta, mikä kuvastaa elämän epävarmuutta tutkimusalueella. Väestönkasvua ja vähenemistä esiintyy tutkimusalueen kaikissa osissa. Rintamailla kasvu liittyy palvelukeskusten kasvuun tai uusien teollisuusalueiden syntyyn, syrjäseuduilla työtilaisuuksien tarjontaan tai asutusalueiden perustamiseen.

Väestöllisillä ilmiöillä on myös keskinäisiä riippuvuussuhteita. Niinpä sukupuolijako korreloi väestönmuutokseen. Korrelaatiot ovat lisäksi erisuuntaisia miespuolisen ja naispuolisen väestön kohdalla. Näytteenä tutkituilla haja-asutusalueilla ja taajamissa taas eri ikäluokkien suuruuksien vaihtelut ja ikäluokkien sukupuolijakojen vaihtelut seuraavat jossainmäärin toisiaan. Näin väestölliset ilmiöt heijastavat alueiden ekologisia olosuhteita, joilla on vaikutusta sekä väestön sukupuoli- että ikäjakautumaan.

\section{Kirjallisuus}

Aario, Leo. Luonnollinen väestönlisäys 1951-55. Suomen kartasto 1960, kartta 12/12. Aario, Leo. Suomen maantiede. Helsinki 1966.

Aario, Leo ja Smeds, Helmer. Väestö ja peltoala I-III. Suomen kartasto 1960, kartat 15-17. 
Ajo, Reino. Rovaniemen allas väkiluvun keskimääräisen vuosikasvun maantieteellisen vaihtelun ilmentämänä ja altaan muuttovoittoisuuden aikavaihteluista suhdannekehityksen valossa vapaan muuttoliikkeen olosuhteissa 1866-1939. Terra 74, N:o 1. 1962.

Alameri, Rolf. Muutamia havaintoja mies- ja naisenemmyydestä Suomen maalaiskunnissa 1910-1950. Väestöntutkimuksen vuosikirja VI, 39-45. Helsinki 1960.

Fogelberg, Paul. Finlands tätorter 1960. Terra 75, N:o 3. 1963.

Fontell, A. G. Luonnollinen väestönlisäys 1891-1900. Suomen kartasto 1910, kartta $4 / 27$.

Fontell, A. G. Luonnollinen väestönlisäys 1901-1907. Suomen kartasto 1910, kartta $8 / 27$.

Fontell, A. G. Luonnollinen väestönlisäys 1818-1822. Suomen kartasto 1910, kartta $3 / 28$.

Hautamäki, Lauri. Kylät, koulupiirit ja äänestysalueet. Terra 79, N:o 2. 1967.

Hult, Juhani. The Areal Differentation of Farming in the Oulu District, Finland. Fennia 94, N:o 2. Helsinki 1966.

Hustich, Ilmari. Suomen taloudellinen aluejako. Terra 72, N:o 3. 1930.

Lapin läänin taajamat. Lapin läänin aluesuunnittelun kuntainliitto, tutkimusjulkaisu N:o 1, 1963.

Lento, Reino. Väestö ja hyvinvointi. Porvoo-Helsinki 1956.

Naukkarinen, Arvo. Kolarin kunnan väestönkehityksestä sekä väestön ikä- ja sukupuolirakenteesta esimerkkinä Pohjois-Suomessa tapahtuvasta väestönkehityksestä. Lapin tutkimusseuran vuosikirja VII. Kemi 1966.

Okko, Veikko. Moreeniaines ja pohjavesi kasvimaantieteellisenä tekijänä ,Lapin kolmiossas. Terra 58, N:o 1. 1946.

Pesonen, Heikki. Oppikoulunkäynti Pohjois-Suomen maaseudulla. Valtakunnansuunnittelu N:o $4-1966$.

Purola, Tapani. Maassamuuton vilkkaus. Porvoo-Helsinki 1964.

STV (Suomen tilastollinen vuosikirja). 1930-1965. Helsinki.

SVT (Suomen virallinen tilasto) VI C: 103. Yleinen väestölaskenta 1960 II. Helsinki 1963.

Tudeer, A. E. Luonnollinen väestönlisäys 1911-1920. Suomen kartasto 1928, kartta $4 / 22$.

Tuura, Antti ja Purola, Tapani. Väestön ja työvoiman kasvu Suomessa vuoteen 1970. Väestöpoliittisen tutkimuslaitoksen julkaisuja A:11. Helsinki 1967.

Valtakunnansuunnittelutoimiston julkaisusarja $A: 16$. Laskelmia väestönkehityksestä Suomen kunnissa vuosina 1930-1990. Helsinki 1964.

Varjo, Uuno. The Finnish Farm. Fennia 92, N:o 1. Helsinki 1965.

Painamattomat 1 ähteet

Johtajaopettajien koulupiirittäiset lokakuun 20. päivän ilmoitukset vuonna 1960 , Tilastollisesta päätoimistosta.

Kuntien henkikirjat 1963-1964.

Kuntien koulupiiri- ja äänestysaluejaot 1960,1964 ja 1966.

Aänioikeutettujen lukumäärät äänestysalueittain 1960, 1964 ja 1966 henkikirjoittajilta. Vähittäiskauppojen myynti vuonna 1960 tohtori Reijo Helteen antamana aineistona. 
Summary:

\title{
Regional Features of Population Structure and Population Changes in Northern Finland
}

\author{
By HEIKKI PESONEN \\ University of Oulu, Institute of Geography
}

The article describes the regional features and main interrelationships between changes in the population and the age and sex structure of the population of the region under investigation by means of cartograms and correlation coefficients.

In rural regions differences are examined in areas that are smaller than the communes, that is, elementary school districts and voting districts are taken as the areal unit of analysis. The characteristics of the inhabitants of these units are studied for the population of compulsory school age and for the enfranchised population. Those of compulsory school age are between 7 and 15 years, while the enfranchised population consists of those over 20 years with no previous criminal record.

Compared to other parts of Finland, the region under investigation is relatively sparsely populated. Habitation is most dense along and at the outlet of the main waterways, along which also the cities and the only borough of the region are located (Figures 1,2 and 3). Other commercial centers can be seen in the cartogram depicting the annual sales of retail stores of areal units (Figure 4).

The study focuses of three statistical regions: Pohjois-Pohjanmaa, Kainuu and Lappi. The population of these regions has increased sharply during the past 35 years (Figure 9). Despite of that, the population in several of the areal units had decreased. Exceptions, however, are those areal units that include population agglomerations, particularly those where the population exceeds 1000 inhabitants (Table 1). The enfranchised population in the major population centers - the cities and the borough of the region - has also increased (Table 2).

In many of the areal units short-term changes in the enfranchised population are the most evident (Figure 5). The agricultural population of the region often cannot gain a sufficient livelihood from their farms alone, but are dependent on outside employment opportunities. These are forestry and road construction works and construction work at a local power station. These employment opportunities are, however, not permanent, and the varying local conditions reflect the short-term changes in the population of the areal units. The growth in the centers is associated with the expansion of service industries.

Inspection of the growth and decrease of the population of areal units during two time periods, instead of looking at short-term population changes, shows the main features of population change (Figure 6). Continuous growth is to be found mainly in those parts of the region under investigation where new settlements have been established after World War II. There the age structure of the population is conducive to the natural increase of the population.

It is characteristic of the sex structure of the population in the areal units that a higher proportion of the enfranchised female population is found in population centers and in more densely populated areas than in other places (Figure 7). This is due to the better employment opportunities of women in these regions than in the more sparsely populated areas, where industries utilizing male manpower predominate.

A relatively large percentage of the population of compulsory school age is found in the new settlements outside the densely populated areas of the region under 
investigation. On the other hand, there are also growing industrial and service centers in the densely populated regions, where the proportion of the population of compulsory school age is also high (Figure 8).

The interrelationship between the changes in the population and population structure was also studied by means of the intercorrelations between them as well as their correlation with some variables characterizing the areal units. These variables are distance from the center of the commune, distance from the nearest city or borough, and population density. Correlations were separately calculated for areal units differing from the usual rural settlements in that they include nonadministrative agglomerations. These areal units were, in addition, also divided into two groups according to the direction of the changes in the population (Tables 3 and 4).

The structures of the correlation matrix of all three groups differ from each other. The statistical significance of the correlations was tested by standard statistical tests, although the variables were not normally distributed.

The interrelationship between the age and sex structure was also analyzed on the basis of the population registers of 8 of the communes under investigation by calculating the proportion of males and females in five age cohorts in different areal units in 1963-1954 (Figure 10). The same data were obtained also for the nonadministrative agglomerations of the region under investigation from the 1930 census, On the basis of these data the relative values in the different age cohorts were calculated as follows:

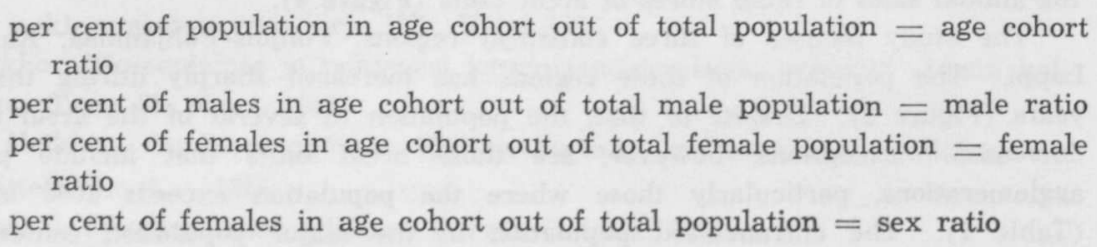

The intercorrelations of these variables were calculated (Tables 5 and 6 ). They reveal the impact of common ecological factors on different age cohorts. However, there is a negative correlation between the proportions in different age cohorts because of the use of ratio variables. Positive correlations show real dependency relationship.

The presence of a correlation between the sex ratio and either the proportion of males or females in a given age cohort indicates whether changes in the proportion of males or females gives rise to the change in the sex ratio. Other correlations between the sex ratio and proportion in a given age cohort indicates the interrelationship between the size of the cohort and the sex structure of the population, while the intercorrelations of the sex ratios show the overall sex structure of the population. 